\title{
Strategi Dalam Menciptakan Kesejahteraan Masyarakat Melalui Rekonstruksi APBN: Telaah Kritis dari Kitab Al-Amwal
}

\author{
Syamsuri $^{\left.1^{*}\right)}$, Setiawan bin Lahuri ${ }^{2)}$, Almas Rizqullah ${ }^{3)}$ \\ 1,2,3Pascasarjana, Universitas Darussalam Gontor \\ *Email korespondensi: syamsuri@unida.gontor.ac.id
}

\begin{abstract}
There are at least two approaches taken by the government to deal with the problem of poverty or create prosperity, namely through fiscal policy and monetary policy. In this article, the author will examine the fiscal policies that should be carried out by the government using the reallocation method of state revenue and expenditure funds or the so-called APBN. Several Muslim figures have studied the problem solving, such as, AsSyaibani and Umar bin Abdul Aziz. However, the author focuses on the contribution of Muslim scholar who was born from Byzantine descent in 154/1858, namely Abu Ubaid, his brilliant idea as outlined in the book Al-Amwal in order to create the mashlahat of society in a country. By using a qualitative method with the library research approach and assisted by the final character study approach, it can be concluded that some strategies according to Abu Ubaid are a solution in creating social welfare, namely Zakat, fa'I, khumus, kharja, and jizyah. As well as regarding the import and export of goods, Abu Ubaid uses a strategy of not having zero tariffs in international trade, excise on staples is cheaper, and there are certain limitations to be subject to excise. This means that when goods enter into a country, there is a cut or excise that enters zakat.
\end{abstract}

Keywords : APBN, Abu Ubaid, welfare, al amwal

Saran sitasi: Syamsuri., Lahuri, S. B., \& Rizqullah, A. (2021). Strategi Dalam Menciptakan Kesejahteraan Masyarakat Melalui Rekonstruksi APBN: Telaah Kritis dari Kitab Al-Amwal. Jurnal Ilmiah Ekonomi Islam, 7(02), 748-755. doi: http://dx.doi.org/10.29040/jiei.v7i2.2057

\section{DOI: http://dx.doi.org/10.29040/jiei.v7i2.2057}

\section{PENDAHULUAN}

Pertumbuhan ekonomi adalah proses perubahan kondisi perekonomian suatu daerah dengan tujuan kondisi perekonomian yang lebih baik. Pertumbuhan ekonomi Indonesia pada saat ini tidak terlepas dari permasalahan- permasalahan yang terdapat di Indonesia. Bukan hanya dalam kasus mikro saja, seperti kekakuan harga, monopoli, serta eksternalitas yang membutuhkan campur tangan pemerintah, namun permasalahan dalam skop makro pun belum terlepas dari negeri ini. Beberapa permasalahan yang belum terselesaikan adalah kemiskinan, kesenjangan ekonomi serta pengangguran yang terus bertambah. Bahkan bukan sebatas perihal tersebut, inflasi yang tidak terkontrol, ketergantungan terhadap import serta hutang luar negari pun menjadi permasalahan pemerintah dalam bidang ekonomi. (Imamul Arifin, 2009) Terdapat tujuh asas dalam melaksanakan pembagunan ekonomi islam yaitu worldview Islam sebagai acuan pembangunan, manusia sebagai pelaku pembangunan, alam roh, alam dunia dan alam akhirat sebagai skala waktu pembangunan, ilmu fardhu 'ain sebagai rangkaan, ibadah sebagai perkaudahan, sumber alam sebagai alat pembangunan, marİotillah merupakan tujuan akhir dari pembangunan. (Syamsuri, 2019)

Secara umum system perekonomian islam menjadi tiga sector yakni public, swasta. Dan keadilan social.(I. P. Syamsuri, 2018) Setidaknya untuk mengatasi berbagai permasalahan ekonomi tersebut, pemerintah mempunyai dua pendekatan, yakni melalui kebijakan moneter dan kebijakan fiskal. Kebijakan moneter adalah kebijakan yang digunakan pemerintah untuk mengontrol uang yang beredar dalam masyarakat melalui bank sentral guna mengendalikan kondisi perekonomian negara. Sedangkan, kebijakan fiskal merupakan kebijakan ekonomi yang digunakan pemerintah untuk mengatur 


\section{Jurnal Ilmiah Ekonomi Islam, 7(02), 2021, 749}

dan mengembalikan perekonomian ke keadaan yang lebih baik (perkembangan ekonomi meningkat), biasanya dengan metode merelokasikan dana penerimaan pengeluaran pemerintah atau biasa disebut APBN. (Imamul Arifin, 2009) APBN menjadi salah satu hal penting dalam kesejahteraan masyarakat. Salah satunya adalah Dana Alokasi Umum yang berasal dari APBN guna pemerataan keuangan antar daerah dengan nilai minimum yakni $25 \%$ dari anggaran rutin. Tujuan dari Dana Alokasi Umum tersebut adalah pemerataan dengan memperhatikan potensi-potensi daerah, keadaan geografis dan jumlah penduduk serta tingkat pendapatan masyarakat pada suatu daerah.(Ni Nyoman Sri Ayu Lestari, I Wayan Bagia, 2015)

Banyak masyarakat Indonesia yang menderita kemiskinan, khususnya pada aspek pengangguran dikarenakan masyarakat Indonesia tidak memiliki lapangan kerja. Berdasarkan hal tersebut As-Syaibani lebih menekankan penyelesaian kemiskinan tersebut dengan menyediakan berbagai macam lapangan pekerjaan.(A. A. Z. Syamsuri, 2020) Berbeda dengan Umar bin Abdul Aziz, dalam menentaskan kemiskanan Umar bin Abdul Aziz lebih menekankan dalam pengelolaan zakat. (Khaerul Aqbar, 2019) Abu Ubaid seorang scholar muslim lahir dari keturunan Byzantium pada tahun $154 \mathrm{H} / 1858 \mathrm{M}$, memiliki ide brilian dalam rangka memelihara serta mempertahankan hak dan kewajiban masyarakat dalam suatu negera, termasuk menjadikan keadilan sebagai prinsip utama dalam melaksanakan kebijakankebijakan pemerintahan dan menekankan rasa tanggung jawab antar sesama. Selain itu, Abu Ubaid juga mewajibkan pemerintah untuk memberikan jaminan standart hidup yang layak kepada masyarakat-masyarakat muslim. (Febriani, 2017) Berdasarkan latar belakang di atas dan kompleksitas permasalahan ekonomi di Indonesia, maka penulis tertarik untuk menganalisa pemikiran ekonomi $\mathrm{Abu}$ Ubaid melalui kajian kitab fenomenalnya yaitu alAmwal dalam merealisasikan Anggaran Pendapatan Belanja Negara (APBN) guna menciptakan kemaslahatan ekonomi masyarakat.

\section{METODE PENELITIAN}

Dalam mengkaji penelitian ini maka metode yang digunakan adalah metode kualitatif dengan melakukan pendekatan library research. Library reseach memanfaatkan berbagai macam sumber perpustakaan guna mendapatkan data data penelitiannya. Dan menjadi penegasan disini bahwa riset ini sangat membatasi kegiatannya, riset ini hanya menggunakan koleksi mengenai perpustakaan saja tanpa memerlukan riset dilapangan. (Mestika Zed, 2014) penelitian ini juga dibantu dengan pendekatan dalam penelitian stuid tokoh. Studi tokoh adalah sebuah penelian mengenai kehidupan seorang tokoh yang memiliki hubungan terhadap masyarakat, sifat, watak, ide, pemikiran, dan pengaruh pemikirannya dan idenya dalam perkembangan sejarah. (Syahrin Harahap, 2014) Konsep pengumpulan data dalam penelitan studi tokoh yakni dengan mengumpulkan berbagai macam kepustakaan seperti: mengumpulkan karya karya tokoh yang memiliki kepribadian yang baik maupun karya yang baik mengenai topik-topik yang sedang diteliti. Kedua, dengan menelaah berbagai macam karya orang lain yang memiliki kesamaan topik atau tokoh. (syahrin Harahap, 2014)

Dengan menggunakan pendekatan yang library reseach dan pendekatan studi tokoh, maka penulis mereview dan menelaah kembali kembali kitab alamwal, dengan harapan mampu menafsirkan pemikiran abu Ubaid lebih sistematis, logis, dan signifikan.

\section{HASIL DAN PEMBAHASAN}

\subsection{Anggaran Pendapatan dan Belanja Negara}

Menurut undang-undang 45 pasal 23 yakni anggaran pendapatan dan belanja negara merupakan suatu wujud dari pengelolaan keuangan suatu negara yang telah ditetapkan setiap tahun dengan undangundang dan dilaksanakan dengan terbuka dan memiliki tanggung jawab atas kemakmuran masyarakat. (UUD 1445 pasal 23 ayat 1) Dalam undang- undang no 17 tahun 2003 tentang keuangan negara, Anggaran Pendapatan dan Belanja Negara (APBN) merupakan rencana keuangan tahunan pemerintah suatu negeri yang disetujui oleh Dewan Perwakilan Rakyat atau DPR. APBN umumnya diawali dari 1 Januari serta berakhir pada tanggal 31 Desember tahun anggaran yang direncanakan. (Sukwiati, dkk, 2009). APBN menggambarkan sesuatu instrument untuk mengendalikan pengeluaran serta pemasukan negara dalam rangka membiayai penerapan aktivitas pemerintahan serta pembangunan, menggapai perkembangan ekonomi, menambah pendapatan nasional, meraih stabilitas perekonomian, serta memastikan arah dan prioritas pembangunan secara universal. (Ni Nyoman Sri Ayu Lestari, I Wayan Bagia, 2015) Secara umum APBN terdiri dari 
pendapatan negara, belanja negara, dan pembiayaan. menurut keterangan dari UU nomor 17 tahun 2003 pula tentang keuangan negara, pendapatan negara merupakan hak pemerintah pusat yang dinyatakan sebagai penambah nilai kekayaan bersih. adapun pembiayaan ialah setiap penerimaan yang perlu ditunaikan kembali dan/atau pengeluaran yang akan diterima kembali, baik pada tahun anggaran yang terkait maupun tahun-tahun anggaran berikutnya. (Mohammad Khusaini, 2019) Penggunaan Anggaran Pendapatan dan Belanja Negara pada saat ini sangatlah membengkak. Khususnya pada pengeluaran guna pembangunan infrastruktur-infrastruktur. Salah satunya adalah pembanguan jalan tol yang menjadi salah satu pengeluaran terbesar APBN pada saat ini.

Dengan banyaknya infrastruktur yang dibangun, dapat ditinjau kembali bagaimana dengan keadaan masyarakat yang masih banyak dalam keadaan miskin dan tidak memiliki lapangan kerja. Ada beberapa fungsi yang harus dipenuhi oleh anggaran pendapatan dan belanja negara. Fungsi fungsi tersebut adalah fungsi alokasi, fungsi distribusi dan fungsi stabilisasi. (Alam S, 2007) Makna dari fungsi alokasi yaitu anggran negara harus ditujukan untuk meminimalisir pengangguran dan pemborosan sumber daya, serta menambah efisiensi dan efektivitas perekonomian. Sedangkan fungsi distirbusi merupakan anggaran yang digunakan untuk menyeratakan pendapatan masyarakat. Serta makna dari fungsi stabilisasi ialah bahwa suatu anggaran pemerintah menjadi alat untuk menjaga dan mengupayakan keseimbangan fundamental perekonomian. (Joko Untoro dan tim, 2010) Pada dasarnya,tujuan penyusunan APBN adalah menjadi suatu pedoman pendapatan dan pembelanjaan suatu negara dalam menjalankan tugasnya dalam kenegaraan guna meningkatkan produksi dan kesempatan kerja, dalam rangka mengembangkan peningkatan ekonomi dan kesejahteraan masyarakat. (Alam S, 2007)

\subsection{Profil Abu Ubaid}

Abu Ubaid ialah seorang yang ahli dalam berbagai hal, seperti ekonomi islam,hukum, hadist dan juga mahir dalam Bahasa arab atau nahwu. Abu Ubaid dilahirkan di bahrah atau harat yang berada di provinsi khurasan tepatnya provinsi tersebut berada di barat lau Afghanistan. yakni dari suku Azad. Nama asli Abu Ubaid adalah Al-Qasim ibn Sallam ibn Miskin ibn Zaid al-Harawi al-Azadi al-Baghdadi dan beliau wafat di kota asalnya pada tahun $224 \mathrm{H}$. Abu Ubaid belajar pertama kali di kota Makkah. Pada saat menginjak 20 tahun umurnya, Abu Ubaid pergi ke Kufah,Basrah, dna Baghdad untuk belajar Bahasa arab, qiraah, tafsir, hadist dan ilmu fiqh. Pada tahun 192 H Abu Ubaid ditunjuk sebagai Qadi di Tarsus sampa tahun $210 \mathrm{H}$ oleh Thabit ibn Nasr ibn Malik. Pada tahun219 H, setelah berhaji Abu Ubaid memutuskan untuk tinggal di kota Makkah sampai wafatnya. (Lailatul Qadariyah, 2018)

Abu Ubaid hidup pada masa khalifah Daulah Abassyah, yakni pada masa Khalifah al Mahdi (158/775 M). Dalam penelitian Najatullah Siddiqi, masa al Mahdi ini ditemukan tiga tokoh terkenal yang menuliskan karya dalam bidang ekonomi, sedangkan pada masa Abasiyah pertama ini, ditemukan lebih dari 200 orang pemikir yang terdiri selain fuqaha juga filusufis, masa Abasiyah ini merupakan kegemilangan dunia Islam atau masa renaisance. Dengan tidak meninyimpang dari nilai keadilan dan keberadaban, Abu Ubaid lebih secara historis mementingkan aspek rasionalitas, nalar dan spritual terhadap kehidupan manusia, baik sebagai individu maupun masyarakat. Atas dasar itu, Abu Ubaid menjadi salah seorang pioner yang menawarkan nilai-nilai tradisional pada abad ke III H, yang mana ia berpendapat bahwa revitalisasi dari sistem perekonomian, dapat diupayakan melalui reformasi terhadap akar-akar kebijakan keuangan serta institusi ekonomi dengan di dasarkan berdasarkan Quran dan Hadis. Dengan kata lain, bersumber dari yang suci Al-Quran dan Hadist, guna mendapatkan nilai-nilai eklusif serta yang kemudian diimplementasikan pada pemikiran ekonomi.(Hidayat, 2019)

Kitab Al-Amwal adalah karya dari Abu Ubaid dan menjadi kitab yang fenomenal yang didalamnya membahas luas mengenai kitab Al-Kharaj yakni karya Abu Yusuf. Focus pembahasannya adalah maslaah keuangan public, walauun mayoritas didalamnya membahas permasalahan administrasu pemerintahan. Didalamnya juga menekankan beberapa issu mengenai perpajakan, hukum, serta hukum administrasi dan hukum internasional. Kitab ini pula sangat memberikan informasi yang penting mengenai kesuksesan pemerintahan dalam meregulasikan berbagai macam kebijakan kebijakan seperti keberhasilan Umar bin Khattab dan Umar bin Abdul Aziz dalam membangun sistemperpajakanyang islami serta memberi kemaslahatan social. (Febriani, 2017) 


\section{Jurnal Ilmiah Ekonomi Islam, 7(02), 2021, 751}

\subsection{Konsep keadilan dalam menciptakan kemaslahatan}

Pada kitab al-Amwal, Keadilan adalah prinsip utama yang di tekankan oleh Abu Ubaid. Keterangan terbaik Abu Ubaid adalah kepentingan umum harus lebih didahulukan daripada kepentingan individu, karena urusan tersebut yang akan membawanya kepada kemashlahatan. Salah satu pemikiran Abu Ubaid dalam kepemimpinannya yakni berani memutuskan kebijakan yang tidak berlawanan dengan syari'ah islam dan selalu berasaskan prinsip kemashlahatan bagi umat islam. Seperti halnya, bahwa zakat tabungan dapat diberikan langsung kepada mustahiq, sementara zakat komoditas harus diserahkan kepada pemerintah. apabila tidak maka kewajiban agama belum ditunaikan. Ia sangat menekankan terhadap pembendaharaan suatu Negara yang tidak boleh disalahgunakan untuk kepentigan pribadi, dengan makan lain, perbendaharaan suatu negara harus digunakan untuk kemaslahatan masyarakat publik. (Lailatul Qadariyah, 2018)

Kesejahteraan dalam islam yang dikemukaan oleh al-mawardi berpendapat bahwa Allah telah menciptakan kita agar kita berkerjasama dengan orang lain dan kita tidak sanggup dengan memenuhi kebutuhan kita sendiri.(D. I. Syamsuri, 2019) Kesejahteraan dalam ekonomi islam tidak hanya memandang distribusi ekonomi secara materi, akan tetapi kesejahteraan tersebut juga mengaitkan dalam unsur non materi dan bidang bidang lainnya. Salah satu cara yang menyangkut unsur materi dalam menegakkan kesejahteraan yakni optimalisasi pengelolaan zakat profesi dengan bebrapa strategi yang dilakukan. Yakni dengan strategi publikasi zakat profesi, strategi aksi dalam pengelolaan zakat profesi dan strategi dalam administrasi pengelolaan zakat profesi. Sedangkan yang menyangkut unsur non materi yakni untuk terealisasinya penghimpunan zakat dari setiap instansi pemerintah perlu adanya sosialisasi terkait fungsi adanya zakat itu sendiri. Yang kedua adalah zakat sebagai dimensi social tersendiri, dimana zakat berorientasi guna menciptakan harmonisasi kondisi social masyarakat.(Syamsuri, 2018)

Abu Ubaid juga menyinggung mengenai persentase jizyah dan kharja. Beliau menyatakan tentang pentingnya suatu keseimbangan kekuatan keuangan penduduk non muslim dengan kepentingan golongan muslim yang berhak menerimanya. Beliau melarang kepada masyarakat muslim untuk menarik pajak terhadap harta tanah non muslim dengan melebihi apa yang telah diperbolehkan dalam sebuah perjanjian kedamaian. (Lailatul Qadariyah, 2018) dalam kitabnya, Abu Ubaid membahas mengenai peringatan bagi para pemungut pajak ('ashir) dan orang orang yang memungut pajak illegal (maks) dan yang dimaksud dengan penindasan atau melebihi batas. Dalam hadist nabi yang mendasari hal tersebut bahwa, Rasulullah SAW bersabda: seorang Amil secara benar sama dengan seseorang yang berperang dijalan Allah hingga dia kembali pulang kerumahnya, dan dalam hadist lain bahwa Rasulullah bersabda: orang yang melakukan kezaliman dan kecurangan didalamakat,maka dia sama dengan orang yang menolak zakat.(Rizal, 2018)

\subsection{Anggaran Pendapatan dan Belanja Negara Menurut Abu Ubaid}

Dalam rangaka pemerintah menjalankan fusi pelayanan kepada masyarakat, pemerintah mencangkup semua aspek yang selalu berkaitan dengan kehidupan sosial ekonomi masyarakat. Artinya, kesejahteraan masyarakat menjadi salah satu tanggung jawab pemerintah setempat. Maka dari itu, berbagai bentuk kebijakan pemerintah seperti kebijakan politik dan kebijakan ekonominya harus selalu memihak kepada masyarakat. Pemerintah islam membutuhkan dana untuk sekian banyak pembiayaan dalam menjalakan roda pemerintahannya. Di dunia Islam, pemerintahan memerlukan dana untuk menggunakan APBN untuk mengendalikan pengeluaran pemerintah, yang sesuai dengan jumlah pendapatannya. Tujuan dari anggaran pemerintah adalah menopang tujuan yang ingin dicapai oleh pemerintah. Tujuan pokok dari setiap pemerintahan Islam adalah memaksimalkan kesejahteraan seluruh warga negara dengan tidak mengabaikan prinsipprinsip keadilan. Lebih jauh lagi, dalam Islam yang dimaksud dengan kesejahteraan bukanlah sematamata diperoleh dari kekayaan material, yang setiap tahun dapat diukur dengan statistik pendapatan nasional, tetapi termasuk juga kesejahteraan rohani di dunia akhirat. Dana tersebut digunakan pemerintah untuk mengendalikan dan menyesuaikan pendapatan dan pengeluaran pemerintah. Anggaran pemerintah tersebut bertujuan sebagai penopang berbagai macam cita cita yang ingin dicapai oleh pemerintah tersebut. Sedangakn tujuan pokok dalam pemerintahan islam ialah mensejahterakan masyarakat suatu negara dengan maksimal tanpa mengabaikan prinsip keadilan yang ada. (Rahmawati, 2012) 


\section{Jurnal Ilmiah Ekonomi Islam, 7(02), 2021, 752}

Baitul Maal sebagai temapat pengelolaan keuangan sauatu negara pada pemerintahan islam terdahulu. Dilihat dari namanya Baitul Maal berasal dari bahasa arab yakni البيت yang berarti rumah dan المال yang berarti harta. (Marimin, 2014) ketika zaman pemerintahan Rasulullah SAW, Baitul Maal menjadi salah satu lembaga keuangan yang ada. Dan kepopuleran lembaga ini sampai pada era Khulafaur Rasyidin yang memilikifungsi menjadi tempat penyimpanan harta kekayaan suatu negara dari zakat, infaq, shadaqah, pajak,serta sampai harta dan barang barang hasil rampasan perang.(Marimin, 2014) Pada tahun ke-2 hijriah terjadi perselisihan antar sahabat mengenai pembagian harta rampasan setelah perang badar, dan Allah turunkan surat Al-Anfal ayat ke 41 yang berisi mengenai penjelasan tentang seperlima dari perolehan harta rampasan adalah untuk Allah, rasul, kerabat rasul, anak-anak yatim, orang-orang miskin dan ibnu sabil. Maka dari itu dengan turunnya ayat ini, Rasulullah SAW memulai pembangunan baitul Mal yang berfungsi sebagai lembaga yang menangani setiap pendapatan Negara serta sebagai tempat penyimpanan harta kaum muslimin. Hakikatnya baitul mal sudah berdiri sudah berdiri sejak zaman Rasulullah, namun belum ada tempat yang khusus dan resmi.(Moh. Ahyar Maarif, 2019)

Pada masa pemerintahan Rasulullah, beliau menjadi salah satu kepala negara yang pertama kali menyebarluaskan konsep keuagan negara, yakni seluruh pendapatan negara dikumpulkan terlebih dahulu dan untuk pembelanjaannya hanya sesuai dengan kebutuhan negara yang diinginkan, dan yang menjadi titik kuatnya adalah barang tersebut bukan dimiliki oleh individu, akan tetapi seluruh barang tersebut menjadi milik negara. Dan ketika pemerintahan Rasulullah SAW, Baitul Maal dipusatkan di masjid nabawa, sehingga pada saat itulah masjid tidak hanya digunakan masyarakat sebagai tempat ibadah, akan tetapi digunakan sebagai kantor keuangan negara. (Moh. Ahyar Maarif, 2019) dan perlu diketahui pula ada ada beberapa harta yang menjadi pemasukan untuk keuangan suatu negara. Harta tersebut didapat dari zakat, fa'i, khumus, kharaj dan jizyah.

a. Zakat

Zakat secara bahasa yakni memiliki makna pensucian, pertumbuhan, dan keberkahan. Menurut istilah, zakat merupakan kewajiban seorang muslim untuk mengeluarkan sebagian dari kekayaannya yang tidak melebihi satu nisab.
(Andri Soemitra, 2018) zakat ini memiliki istilah lain yakni shodaqah wajib yang terdiri atas zakat emas, zakat perniagaan, zakat buah buahan, zakat biji-bijian, zakat kambing, zakat sapi dan zakat unta. Pengalokasian zakat tersebut kepada golongan golongan yang telah Allah tetapkan didalam Al-Quran. Mereka adalah fakir, miskn, pengelola zakat, orang yang baru masuk islam atau muallaf, budak atau hamba sahaya, orang yang terlilit hutang, orang yang jihad di jalan Allah, orang yang dalam perjalanan.(Abdurrauf Az-Zawwawi, 2019). Abu Ubaid juga mengungkapkan beberapa ketentuan terhadap muslim yang wajib mezakati dari 8 golongan tersebut, diantaranya memiliki 200 dirham, 20 dinar, 5 ekor unta, 30 sapi, atau 40 ekor kambing.(Ghozali \& Khoirunnisa, 2018)

b. Fa'i

Fa'i adalah harta yang didapatkan masyarakat islam tanpa melakukan pertempuran dengan pasukan berkuda atau berkendara lain. Satu perlima dari harta fa'i diberikan kepada orang orang yang berhak mendapatkannya yakni seperti yang telah disebutkan pada surah Al-Hasyr ayat 7, yakni untuk Allah, Rasul, kerabat Rasul, anak yatim,orang-orang miskin dan orang-orang dalam perjalanan.(Ali Muhammad Ash-Shalabi, 2008). Sedangkan menurut Abu Ubaid Fa'i merupakan sesuatu yang diambil dari harta dzimmah suatu perdamaian atas jizyah dari mereka. Dan harta fa'i tersebut dimanfaatkan untuk kepentingan pemerintahan dan kemaslahatan masyarakat. (Lailatul Qadariah,2018)

c. Khumus

Abu Ubaid menyatakan khumus adalah satu perlima ghanimah dari ahli harbi,luqathah dan rikaz. Beberapa harta yang termasuk khumus yakni ghanimah sebagaimana firman Allah pada surat al-anfal ayat 41.yang kedua adalah harta yang didapatkan memalui harta yang terpendam (rikaz) dan harta didapatkan dari penambangan. Yang ketiga adalah harta yang dipendam. (Ghozali \& Khoirunnisa, 2018)

d. Kharaj

Kharaj merupakan hak yang diberikan atas lahan tanah yang sudah dirampas dari kaum kafir, baik melaui pertempuran maupun melewati jalan perdamaian. (Isnaini Harahap,dkk, 2017) Tanah tersebut digunakan untuk lahan-lahan pertanian, 


\section{Jurnal Ilmiah Ekonomi Islam, 7(02), 2021, 753}

barang siapa yang ingin mengurus lahan tersebut maka diwajibkan untuk membayar sewa. Pendapatan dari sewa tersebutlah yang dimaksud dalam kharaj. Apabila terjadi perselisihan antara masyarakat muslim dan non-muslim, maka mereka membuat sebuah perjanjian yakni apabila pengelelola tersebut adalah non-muslim maka mereka wajib membayar pajak. Pajak tersebut yang dinamakan kharaj, sedangkan apabila yang mengelola adalah masyarakat muslim, maka masyarakat muslim wajib membayar sewa. Biaya sewa tersebut yang termasuk dalam ruang lingkup kharaj.(Febriani, 2017)

e. Jizyah

Al-jizyah dalam arti bahasa adalah pajak tanah, sebuah pajak yang didapatkan dari kaum kafir dzimmiy. Dalam pelaksanaannya, jizyah disebut sebagai pajak yang dibebankan kepada masyarakat non muslim yang menetap dinegara islam, yang sekaligus menjadi jaminan bagi mereka untuk mendapatkan keamanan, kenyamanan, kemudahan dalam bertransaksi dengan muslim, sebuah kesejahteraan dan mendapatkan jaminan keamanan atas harta mereka. Ketentuan jizyah tergantung pada suatu pemerintahan pada masa itu. (Wahyu Nugroho, Syamsuri, Syamsuddin Arif, 2019)

Pemikiran Abu Ubaid yang telah dijelaskan didalam kitab Al-Amwal tehadap ekspor dan impor barang di bagi menjadi tiga bagian, yakni tidak adanya nol tarif dalam sebuah perdagangan international, yang kedua adalah cukai dalam bahan makanan tersebut lebih murah serta ada batasan batasan tertentu untuk dikenakan cukai.

a. Tidak adanya nol tarif dalam sebuah perdagangan internatioal

Mengumpulkan cukai yakni termasuk dalam kebiasaan masyarat pada zaman jahiliyah. Hal tersebut dikarenakan mereka selalu mengambilcukai barang dagangan import atas harta mereka apabilai barang tersebut masuk kedalam negara mereka. Akan teteapi pada masa pemerintahan Abu Ubaid, beliau menyimpulkan bahwa cukai merupakan adat kebiasan masyarakat jahiliah. Kemudian Allah melarang cukai tersebut dan mengutus Rasulullah dan agama Islam, kemudian datanglah kewajiban membayar kewajban dalam membayar zakat sebesar satu perempat dari usyur (2,5\%). Ziyad bin hudair pula pernah berkata bahwa beliau di lantik oleh umar sebagai petugas bea cukai. Dan Umar memerintahkan Ziyad untuk mengambil cukai barang impor dari pedagang kafrharfi sebnyak usyur $(10 \%$,) dari ahli dzimmah sebanyak setengah dari usyur atau $5 \%$ dan barang dari kaum muslimin sebanyak $2.5 \%$ atau seperempat usyur.(Ghozali \& Khoirunnisa, 2018)

b. Cukai pada bahan makanan tersebut lebih murah Cukai pada bahan makanan pokok seperti minyak dan gandum bukan usyur atau $10 \%$ akan tetapi setengah usyur atau $5 \%$. Hal tersebut bertujuan agar barang bahan makan pokok berbondongbondong berdatangan ke pusat pemerintahan pada saat itu yakni kota Madinah. (Safitri \& Fakhri, 2017)

c. Ada batasan batasan tertentu untuk dikenakan cukai

Tidak semua barang dagangan dikenakan biaya cukai. Ada pula batasan batasan tertentu mengenai barang tersebut. Apabila barang tersebut kurang dari batasnya maka tidak akan dikenakan cukai. Batasan tersebut yakni setiap 20 dinar harus dikenakan cukai sebesar 1 dinar. Apabila jumlah kurang dari yang disebutkan maka tidak dikenakan cukai.(Safitri \& Fakhri, 2017) Menurut Abu Ubaid yang menjadi kadar terendah dalam pengumpulan cukai atas harta impor ahli dzimmah dan kafir harbi yakni seratus dirham.(Ghozali \& Khoirunnisa, 2018)

\subsection{Peran APBN dalam menciptakan kesejahteraan dan relefansinya di Indonesia}

APBN adalah salah sauatu kebijakan pemerintah yang digunakan untuk tercapainya masyarakat yang makmur dan sejahtera. Seperti Kebijakan APBN pada tahun 2020 yang telah ditetapkan dalam berbagai bidang, yakni bidang Pendidikan, bidang Kesehatan, bidang perlindugan social,dan infrastruktur. Tujuan dalam kebijakan tersebut adalah agar sumber daya manusia harus dapat beradaptasi dengan kemajuan industry dan teknologi. Tidak hanya itu, banyak pengeluaran APBN yang kembali kemasyarakat guna mensejahterakan masyarakat. Sebagai bukti bahwa adanya penurunan yang signifikan mengenai kemiskinan di negara kita. Sejak tahun 2007 yang memiliki tingkat kemisikinan $16,58 \%$ dengan berbagai pendekatan pembangunan guna pengentasan kemiskinan maka tingkat kemisikinan menurun menjadi $9,66 \%$ pada tahun 2018. Sebagai contoh 


\section{Jurnal Ilmiah Ekonomi Islam, 7(02), 2021, 754}

yakni Program Pangan Non Tunai (BPNT) yakni bantuan untuk masyarakat miskin guna memenuhi kebutuhan pokoknya, Program Keluarga Harapan (PKH) merupakan program perlindungan masyarakat miskin dan mendorong kepada behaviour positif, yang ketiga adalah Program Bantuan Iuran Jaminan Kesehatan Nasional (PBI JKN). Program ini berguna untuk memastikan $40 \%$ masyarakat termiskin dapat memiliki akses ke fasilitas Kesehatan. dan Program lainnya adalah Indonesia Pintar (PIP) yang merupakan bantuan siswa miskin agar tetap menerima Pendidikan yang bersetandart demi mendapatkan kelangsungan hidup pada masa yang akan datang. (https://www.kemenkeu.go.id)

\section{KESIMPULAN}

Konsep pemikiran APBN Abu Ubaid dengan APBN pada era sekarang sangat berbanding terbalik. Pada era pemerintahan Abu Ubaid, setiap pengelolaan keuangan seluruhnya dipusatkan di dalam Baitul Maal. Dan dalam pemikiran Abu Ubaid pula pemerintah harus memberikan jaminan standar kepada masyarakat muslim. Ada beberapa konsep keuangan negara yang didapatkan dari masyarakat yakni seperti zakat, jizyah, khumus, kharaj, dan fa'i. Selain daripada itu ada tiga konsep pemikiran ekonomi dalam pengelolaan keuangan negara yang termaktub dalam kitabnya "al-amwal" yaitu mengenai impor dan ekspor barang. hal tersebut yakni tidak adanya nol tarif dalam sebuah perdagangan international, cukai bahan pokok tersebut lebih murah, dan terdapat batasan-batasan tertentu untuk dikenakan cukai. Maksudnya mengenai barang yang masuk ke dalam suatu negara terdapat pemotongan atau cukai yang masuk ke dalam zakat.

\section{UCAPAN TERIMA KASIH}

Alhamdulillah, penelitian ini dengan judul Anggaran Pendapatan Belanja Negara dalam pemikiran Abu Ubaid dapat terselesaikan sebagaimana mestinya. Kami ucapkan ribuan terimakasih kepada dosen pembimbing, teman teman, dan puhak pihak yang berkontribusi dalam penyelesaian penelitian ini. Semoga apa yang ada didalam penelitian ini bisa menjadi pahala jariyah dan manfaat bagi para pembaca-pembaca setelahnya. Aamiin Ya Rabbal Alamin.

\section{REFERENSI}

Arifin, Imamul. 2009. Membuka Cakrawala Ekonomi 3: untuk Kelas XII Sekolah Menengah atas/Madrasah Aliyah. Jakarta: Pusat Perbukuan, Departemen Pendidikan Nasional.

Ash-Shalabi, Ali Muhammad. (2008). Biografi Umar

Bn Al-Khathab. Jakarta Timur: Pustaka AlKautsar

Az-Zawawi, Abdurrauf.(2019). Al-Baqiyatus Shalihat.Jakarta Timur: Pustaka Al-Kautsar.

Febriani, A. (2017a). Pemikiran Ekonomi Abu Ubaid Al-Baghdadi (Studi Kitab Al-Amwaal). Jurisprudensi Iain Langsa, pp. 128-149.

Febriani, A. (2017b). Pemikiran Ekonomi Abu Ubaid Al-Baghdadi (Studi Kitab Al-Amwaal). Jurisprudensi Iain Langsa.

Ghozali, M., \& Khoirunnisa, R. (2018). KONSEP PENGELOLAAN KEUANGAN ISLAM MENURUT PEMIKIRAN ABU UBAID. Jurnal Ekonomi Dan Bisnis Islam (Journal of Islamic Economics and Business), 4(1), 64. https://doi.org/10.20473/jebis.v4i1.10068

Hidayat, T. (2019). Abu Ubaid sebagai Fuqha dan Ekonom: Critical Reading terhadap Corak Pemikiran dan Konsepsi Ekonomi Ibn Ubaid. AL-FALAH: Journal of Islamic Economics, 4(1), $1-13$.

https://doi.org/10.29240/alfalah.v4i1.781

Khaerul Aqbar, A. I. (2019). Kontekstualisasi Kebijakan Zakat Umar bin Abdul Aziz dalam Perzakatan dan Pengentasan Kemiskinan di Indonesia. Kajian Ekonomi Keuangan, 03(4), 35. https://doi.org/10.31685/kek.v313.503

Marimin, A. (2014). Baitul Maal Sebagai Lembaga Keuangan Islam Dalam Memperlancar Aktivitas Perekonomian. Jurnal Akuntansi Dan Pajak, 14(02), 39-42. https://doi.org/10.29040/jap.v14i02.139

Moh. Ahyar Maarif. (2019). Baitul Mal pada Masa Rasulullah Saw dan Khulafaur Al-Rashidin. Asy-Syari'ah: Jurnal Hukum Islam. https://doi.org/10.36835/assyariah.v5i2.118

Ni Nyoman Sri Ayu Lestari, I Wayan Bagia, G. P. A. S. J. (2015). Pengaruh Anggaran Pendapatan Belanja Negara (Apbn) Terhadap Belanja Langsung Pada Pemerintah Daerah Kabupaten/Kota. Bisma: Jurnal Manajemen, Vol. 4, pp. 24-33. 
Jurnal Ilmiah Ekonomi Islam, 7(02), 2021, 755

Rahmawati, L. (2012). ANGGARAN PENDAPATAN BELANJA NEGARA ( APBN) PEMERINTAHAN ISLAM ( Wacana Politik Ekonomi Islam ) Lilik Rahmawati Dosen Fakultas Syariah IAIN Sunan Ampel Surabaya Abstract Pendahuluan Dominasi ekonomi konvensional saat ini membuat umat Islam dewasa ini diha. 02(01), 232-256.

Rizal, F. (2018). Relevansi Pemikiran Ekonomi Islam Abu Ubaid Dengan Perekonomian Modern. ACTIVA: Jurnal Ekonomi Syariah, 1, 110-128.

Safitri, J., \& Fakhri, A. (2017). Analisis Perbandingan Pemikiran Abu ' Ubaid Al-Qasim dan Adam Smith Mengenai Perdagangan. Millah, 17(1), 85-98.

https://doi.org/10.20885/millah.vol17.iss1.art5

Syamsuri. (2018). Strategi Dalam Meningkatkan Kesejahteraan Ekonomi Melalui Optimalisasi Pengelolaan Zakat Profesi Di BAZNAS Ponorogo. 5(2). https://doi.org/10.19105/iqtishadia.v5i2.1747
Syamsuri. (2019). PENDEKATAN ISLAM DALAM PEMBANGUNAN EKONOMI; SATU KONSEP MENUJU KESEJAHTERAAN UMAT. O2(01), 50-89.

Syamsuri, A. A. Z. (2020). STRATEGI PENGENTASAN KEMISKINAN MELALUI PEKERJAAN DAN DISTRIBUSI MENURUT AS-SYAIBANI DAN RELEFANSINYA DI INDONESIA. El Barka: Journal of Islamic Economic and Business, D(2), 232-256.

Syamsuri, D. I. (2019). Negara Kesejahteraan dan Maqasid Syariah: Analisis Pemikiran Jamaluddin Athiyyah. 4(1), 83-97.

Syamsuri, I. P. (2018). UPAYA PENCAPAIAN KESEJAHTERAAN MASYARAKAT MELALUI PENGELOLAAN PAJAK: RELEVANSI KONSEP AL KHARAJ ABU YUSUF DI INDONESIA. 05, 236-256.

Wahyu Nugroho, Syamsuri, Syamsuddin Arif, D. F. (2019). Zakat dan Jizyah Sebagai Pengendali Sistem Moneter: Sebuah Kajian Konseptual. 5(2), 163-180. 